\title{
PENENTUAN TEKANAN DAN WAKTU OPTIMUM DALAM PEMBUATAN SERBUK TELUR MENGGUNAKAN OVEN VAKUM
}

\author{
Emmanuela Maria Widyanti', ${ }^{*}$, Endang Kusumawati', Agit Fajar Sukmana1, \\ Zaki Maulana Ahmad Mudzakkir ${ }^{1}$ \\ ${ }^{1}$ Jurusan Teknik Kimia, Politeknik Negeri Bandung \\ Jln. Gegerkalong Hilir, Ds. Ciwaruga, Bandung 40012 \\ *E-mail: emmanuela25@ymail.com
}

\begin{abstract}
ABSTRAK
Penelitian tentang pengeringan telur ayam menggunakan oven vakum dilakukan untuk mendapatkan kondisi terbaik dari serbuk telur, sehingga kualitas tidak berubah. Penelitian pendahuluan dalam mendapatkan air dalam kesetimbangan, menggunakan metode tray drying, dilakukan pada suhu $44^{\circ} \mathrm{C}$ untuk menjaga degradasi protein. Air dalam telur mencapai kesetimbangan sebesar 4,84\%. Penentuan tekanan optimum dilakukan pada oven vakum, dengan variasi tekanan 80, 160, 240, 320, 400 mbar Absolut, didapatkan pada 80 mbar Absolut, yaitu terjadi pengurangan massa telur 33,76 g dan kadar air sebesar $4,76 \%$. Variasi waktu pengeringan pada menit ke 40, 80, 120, 160, dan 200, didapatkan penurunan massa telur pada menit ke 160 sebesar 37,87 g dengan kadar air sebesar 1,12\%. Analisis kadar protein serbuk telur menggunakan spektrofotometri metode biuret, didapatkan peningkatan $15,37-80,66 \%$ dan lemak menggunakan ekstraksi soxhlet terjadi penurunan dari 43,53-37,47\%. dari menit 80 sampai 160. Penampilan serbuk telur setelah 25 hari menunjukkan hasil yang baik, karena tidak berubah warna, bau dan fisik.
\end{abstract}

Kata kunci: Oven vakum, pengeringan, tray drying, spektrofotometri, soxhlet

\begin{abstract}
Research has been taken in an oven vacuum to reach stable quality to get the optimum conditions of egg powder drying. The previous research with $44^{\circ} \mathrm{C}$ temperature of tray drying method keeps the number of water content of the egg at $4.84 \%$ equals with airwater content; it's mean the protein of the egg is stable. The pressure of the vacuum is gradually increased from 80, 160, 240, 320, and 400 mbar Abs. Moreover, the optimum result is at 80 mbar Abs. in its condition, the mass of egg is reduced by 33.76 grams, and the water content $4.76 \%$. Vacuum pressure time given in $40,80,120,160$, and 200 minutes. The best result was in 160 minutes that reduced the mass of 37.87 grams in $1.12 \%$ of water content. spectrophotometric biuret method used to analyze the powder egg. Protein increased from 15.37 to $80.66 \%$ and decrease of fat 43.53 to $37.47 \%$ by soxhlet extraction method within $80-160$ minutes. The appearance of the egg powder still in its condition after 25 days, included color, odor, and shape.
\end{abstract}

Keyword: Oven vacuum, drying, tray drying, spectrophotometry, Soxhlet

\section{PENDAHULUAN}

Pengeringan merupakan salah satu proses pengawetan bahan makanan, karena selain tidak mengubah penampilan bahan tersebut, juga tahan bila disimpan dalam waktu tertentu, karena kadar air dalam batas tertentu mengakibatkan mikroorganisme tidak mudah tumbuh. (Winarno, 1994). Kualitas bahan makanan menurun, apabila proses pengeringan 
dilakukan tanpa memperhatikan suhu dan waktu pengeringan. Kerusakan lain adalah perubahan sifat fisik dan kimia.

Telur terdiri dari tiga komponen utama, yaitu bagian kulit telur $8-11 \%$, putih telur (albumen) 57-65\% dan kuning telur 27-32\% (Bell and Weaver, 2002; Cunningham, 1976). Kadar air yang tinggi menyebabkan telur mudah rusak dalam penyimpanan karena mikroorganisme berkembang, maka perlu dilakukan penurunan kadar air, sehingga menjadi serbuk telur. Kadar air yang rendah, yaitu 5-10\% mengakibatakan mikroba tidak bisa hidup (Winarno, 1994).

Penelitian tentang pengeringan telur belum dilakukan, tetapi beberapa peneliti melakukan penelitian pengeringan bahan makanan menggunakan oven vakum untuk menghindari kerusakan kandungan nutrisi dalam bahan tersebut. Beberapa penelitian yang ada dilakukan oleh Yuniarti dkk, 2013, tentang kerusakan kandungan protein, albumin, lemak dalam ikan gabus akibat pemanasan pada suhu tinggi, penelitian ini diambil sebagai acuan mengingat kandungan yang dimiliki ikan gabus hampir sama dengan telur.

Berdasarkan penelitian Yuniarti, dkk maka dilakukan penelitian menggunakan tekanan vakum, sedangkan suhu yang digunakan pada $50^{\circ} \mathrm{C}$, merupakan kondisi pengeringan vakum paling baik berdasarkan kondisi yang didapatkan oleh Kumaravel, dkk. Dengan kondisi ini suhu pengeringan tidak terlalu tinggi, sehingga diharapkan penurunan kadar air kesetimbangan tercapai tanpa merusak kualitas dari serbuk telur.

\section{Komposisi Telur}

Beberapa zat nutrisi yang dikandung telur ayam per $100 \mathrm{~g}$ dapat dilihat pada Tabel 1.
Tabel 1. Komposisi Telur Ayam

\begin{tabular}{lrrr}
\hline Komposisi & $\begin{array}{r}\text { Telur } \\
\text { Utuh }\end{array}$ & $\begin{array}{r}\text { Putih } \\
\text { Telur }\end{array}$ & $\begin{array}{l}\text { Kuning } \\
\text { Telur }\end{array}$ \\
\hline Air (\%) & 73,70 & 88,57 & 48,50 \\
Protein (\%) & 13,00 & 10,30 & 16,15 \\
Lemak (g) & 11,59 & 0,03 & 34,65 \\
Karbohidrat(g) & 0,65 & 0,65 & 0,60 \\
Abu (g) & 0,90 & 0,55 & 1,10
\end{tabular}

Sumber: (Winarno dan Koswara, 2002)

\section{Struktur Telur}

Telur secara fisik diklasifikasikan dalam tiga bagian yaitu cangkang telur (eggshell) $12.3 \%$, putih telur (egg white) $55.8 \%$ dan kuning telur (egg yolk) 31.9\% (Stadelman dan Coteril, 1995). Menurut Robert, 2004 struktur fisik telur terdiri dari tiga bagian utama yaitu $9-12 \%$ merupakan cangkang telur (eggshell), $60 \%$ putih telur (egg white), dan 30-33\% kuning) telur (egg yolk). Berikut ini merupakan gambar struktur telur:

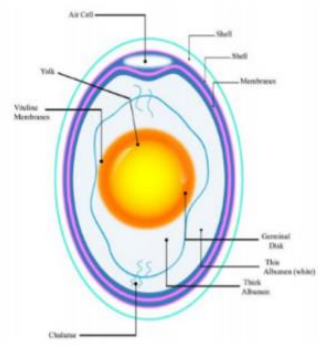

Gambar 1. Struktur telur (Cotterill \& Geiger, 1977).

\section{Kerusakan Telur}

Telur rentan mengalami kerusakan baik secara fisik, kimia ataupun secara biologis. Kerusakan ini bisa diakibatkan pemanasan, penyimpanan terlalu lama dan kontaminasi mikroba (Stadelman dan Coteril, 1995). Selain kerusakan alami, pengeringan akibat suhu tinggi, dapat menurunkan kualitas telur, beberapa kerusakan selama proses pengeringan yaitu

\section{Case Hardening}

Case hardening merupakan masalah dalam proses pengeringan yang menyebabkan kondisi permukaan bahan sudah kering, sedangkan bagian dalam belum kering. Akibatnya permukaan 
bahan akan mengeras dan menghambat proses penguapan air pada bagian dalam bahan. Masalah ini biasanya terjadi karena pemanasan yang terlalu cepat. Pencegahan "case hardening" dilakukan dengan membuat suhu pengeringan tidak terlalu tinggi.

\section{Denaturasi Protein}

Denaturasi protein merupakan kerusakan protein akibat perubahan struktur karena pengaruh panas, yaitu protein akan kehilangan aktivitas biokimianya meskipun kandungan unsurnya $(\mathrm{C}, \mathrm{H}, \mathrm{O}$, dan $\mathrm{N})$ umumnya tidak berubah. Menurut Douglass Baldwin, 2010, kandungan protein dalam telur akan terdenaturasi pada temperatur yang berbeda.

\section{Pengeringan}

Pengeringan adalah metode untuk mengeluarkan air yang terkandung pada bahan menggunakan bantuan panas, proses ini merupakan salah satu pengawetan jika air yang terdapat pada bahan tersebut mencapai batas mikroorganisme tidak dapat tumbuh (Winarno, 1993). Proses pengeringan memiliki beberapa kekurangan, diantaranya berubahnya kandungan bahan dan penurunan kualitas bahan. Beberapa metode pengeringan yang diterapkan pada bahan makanan, yaitu spray drying, freeze drying, vacuum drying. Dua periode utama pada proses pengeringan yaitu periode laju pengeringan konstan (constant rate) dan periode laju pengeringan menurun (falling rate) (Henderson dan Perry, 1995). Kedua periode utama ini dibatasi oleh kadar air kritis. Pada periode pengeringan dengan laju tetap, bahan mengandung air cukup banyak, mengakibatkan penguapan permukaan bahan berlangsung dengan laju sebanding dengan laju penguapan pada permukaan air bebas. Semakin sedikit kandungan air pada suatu bahan akan menurunkan laju pengeringan karena air terikat semakin lama semakin berkurang.

\section{Pengering Vakum}

Pengering vakum merupakan pengering yang dapat bekerja pada suhu dan tekanan yang rendah. Alat pengering vakum yang sering digunakan adalah oven vakum. Prinsip dari pengering vakum adalah mengkondisikan tekanan vakum pada ruang pengeringan sehingga bahan dapat dikeringkan pada suhu rendah. Pengeringan digunakan untuk mendapatkan produk dengan kualitas tinggi, meminimalisir terbuangnya aroma, zat aktif dan volatil (mudah menguap), serta memperkecil kerusakan nutrisi pada bahan, seperti denaturasi protein, browning (pencoklatan bahan), dan reaksi enzimatis.

\section{Pengaruh Suhu, Tekanan dan Waktu Pada Pengeringan Vakum}

Beberapa produk bahan makanan mempunyai temperatur sensitif pada suhu yang lebih tinggi dengan waktu pengeringan yang lama, kondisi tersebut dapat merusak bahan.

Selain sifat fisika dan kimia dari suatu bahan, tekanan juga berpengaruh terhadap proses pengeringan. Tekanan yang rendah akan menurunkan titik didih dari air sehingga pengeringan dapat dilakukan pada suhu yang lebih rendah pula.

Menurut penelitian Yuniarti dkk, 2013, berjudul "Pengaruh Suhu Pengeringan Vakum Terhadap Kualitas Serbuk Albumin Ikan Gabus (Ophiocephalusstriatus)", dengan pemanasan berlebih pada pengering vakum menyebabkan rusaknya albumin, protein, dan lemak. Proses pengeringan yang dilakukan menggunakan variasi suhu pengering vakum $37-53^{\circ} \mathrm{C}$. Kadar albumin dan protein mengalami peningkatan dari suhu $37-49^{\circ} \mathrm{C}$, namun pada suhu $53^{\circ} \mathrm{C}$ mengalami penurunan 
disebabkan rusaknya kandungan albumin dan protein. Pengamatan kandungan lemak yang terdapat pada bahan berbanding lurus dengan pengurangan kadar air atau semakin banyak air yang teruapkan, maka semakin sedikit kadar lemak yang ada. Mengingat kandungan telur juga memiliki albumin, protein, lemak, dan air hampir mirip dengan ikan gabus, maka penelitian Yuniarti dipakai sebagai dasar dalam penentuan suhu. Penelitian Kumaravel, dkk. (2012) yang berjudul "Effect of Oven drying on the nutritional properties of whole egg and its components", bahwa kondisi suhu pengering vakum yang baik dilaksanakan pada $50^{\circ} \mathrm{C}$.

\section{METODE}

Metodologi penelitian dilakukan untuk mengetahui tahapan proses dari awal, sehingga penentuan tekanan dan waktu optimum dalam pembuatan serbuk telur dengan oven vakum. Pengujian hasil mendapatkan serbuk telur sesuai yang diharapkan, disamping dapat mengetahui secara tepat nilai gizi dan kerusakan dari serbuk telur tersebut setelah proses pengeringan.

\section{Tahap Penelitian}

Proses pembuatan serbuk telur secara keseluruhan adalah sebagai berikut :

\section{Perlakuan A wal Telur}

1. Seleksi telur secara manual, sehingga telur yang rusak tidak digunakan, meliputi: pemeriksaan dengan senter, pencucian pada suhu $33-35^{\circ} \mathrm{C}$, pemecahan kulit, pengadukan dengan sendok dan penempatan dalam wadah untuk dikeringkan dengan metode tray drying.

2. Penentuan Kadar air kesetimbangan tahap pengeringan telur dilakukan dengan metode tray drying pada suhu $44^{\circ} \mathrm{C}$. Pengamatan dilakukan dengan mengetahui penurunan berat telur setiap 10 menit selama 200 menit.

\section{Pembuatan Serbuk Telur}

1. Penentuan Tekanan Optimum Pengeringan telur menggunakan oven vakum, pada proses ini serbuk telur yang didapatkan diharapkan mempunyai kandungan air dalam kesetimbangan dengan udara. Dengan didapatkan pada kondisi ini diharapkan air yang ada dalam serbuk telur tidak lagi menurun, selain itu kandungan air serendah mungkin sehingga mikroorganisme tidak tumbuh,

2. Penentuan Waktu Optimum Pengeringan Telur dalam Oven Vakum

Serbuk telur didapatkan pada oven vakum dengan proses sebagai berikut: suhu $\quad 44^{\circ} \mathrm{C}$, tekanan optimum 80 mbar Absolut dan variabel waktu pengeringan $60,80,100,120,140,160$ menit.

Kondisi optimum dalam pengeringan adalah tekanan 80 mbar Abs dan waktu 160 menit, serta suhu pengeringan $44^{\circ} \mathrm{C}$, kondisi tersebut selanjutnya digunakan sebagai variabel proses pembuatan serbuk telur dan dilakukan analisis.

\section{Proses Analisis}

Analisis produk sebagai berikut:

1. Proses pengujian kandungan proteindengan metode spektrofotometri Biuret

Pengujian sebagai berikut:

a.Pembuatan Pereduksi

- Melarutkan $\mathrm{CuSO}_{4}$ dan Na-K

Tartrat dalam $50 \mathrm{ml} \mathrm{NaOH} \mathrm{0,2} \mathrm{N}$

-Menambahkan KI, selanjutnya melakukan pengenceran dengan $\mathrm{NaOH}$ sampai $100 \mathrm{ml}$

b.Pembuatan Larutan Standar

- Memasukkan 0; 0,2; 0,4; 0,6;

0,$8 ; 1 \mathrm{ml}$ protein standar

$(5,0 \mathrm{mg} / \mathrm{ml})$

- Melarutkan dalam $\mathrm{NaCl}$ 0,5 M sebanyak $4 \mathrm{ml}$ 
- Menambahkan biuret sebanyak $10 \mathrm{ml}$

- Menyimpan pada suhu ambient selama 30 menit

- Mengukur absorbansi menggunakan spektrofotometer pada panjang gelombang $540 \mathrm{~nm}$

c.Pengukuran sampel

- Memasukkan 20 mg sampel pada tabung reaksi

- Melarutkan $\mathrm{NaCl}$ 0,5 M sebanyak $4 \mathrm{ml}$

- Menambahkan biuret sampai volume $10 \mathrm{ml}$

- Menyimpan pada suhu ambient selama 30 menit

- Mengukur absorbansi sampel menggunakan spektrofotometer pada panjang gelombang $540 \mathrm{~nm}$

2. Pengujian lemak dengan Ekstraksi Soxhlet

- Mengeringkan labu lemak dalam oven selama 1 jam

- Mendinginkan labu lemak dalam desikator selama 15 menit

- Menimbang labu lemak

- Menimbang sampel dan membungkus dengan kertas saring

- Melakukan ekstraksi menggunakan Soxhlet pada suhu $80^{\circ} \mathrm{C}$ dengan solvent heksana

- Melakukan destilasi suhu $75^{\circ} \mathrm{C}$

- Mengeringkan lemak dalam Soxhlet selama 1 jam pada suhu $100^{\circ} \mathrm{C}$

- Mendinginkan lemak dalam desikator selama 15 menit

- Menimbang berat padatan yang didapat, sebagai kadar lemak

3. Analisis Organoleptik produk, terdiri dari: analisis bau, warna dan tekstur serbuk telur pada pengamatan 25 hari

\section{HASIL DAN PEMBAHASAN}

Penentuan kondisi proses terbaik pengeringan telur ditentukan dengan mencari keadaan saat kadar air pada telur dalam kesetimbangan dengan udara, agar didapatkan kondisi proses yang tepat dan sesuai dengan karakteristik bahan yang digunakan. Penentuan kadar air kesetimbangan menggunakan metode tray drying pada suhu $44^{\circ} \mathrm{C}$. Hasil yang didapatkan yaitu air dalam telur mencapai kesetimbangan dengan udara pada $4,84 \%$,

\section{Penentuan Tekanan Maksimum dalam Pengeringan dengan Oven Vakum}

Penentuan tekanan dilakukan untuk mendapatkan kondisi terbaik serbuk telur yang didapatkan, dan tidak merusak nilai gizi. Penelitian menggunakan variasi tekanan 80, 160, 240, 320, dan 400 mbar Absolut. Hasil yang didapatkan dapat dilihat pada gambar 2. dan 3.

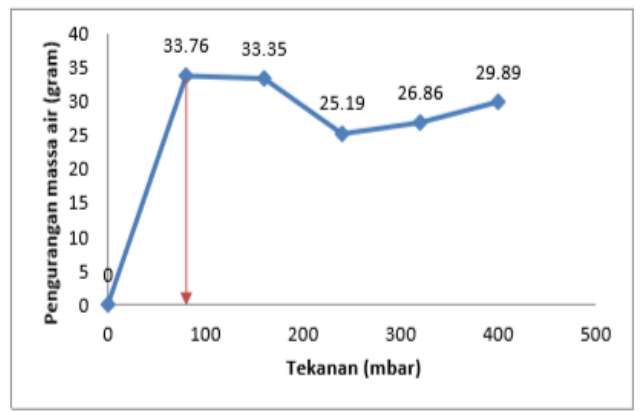

Gambar 2. Grafik pengurangan massa vs waktu pengeringan

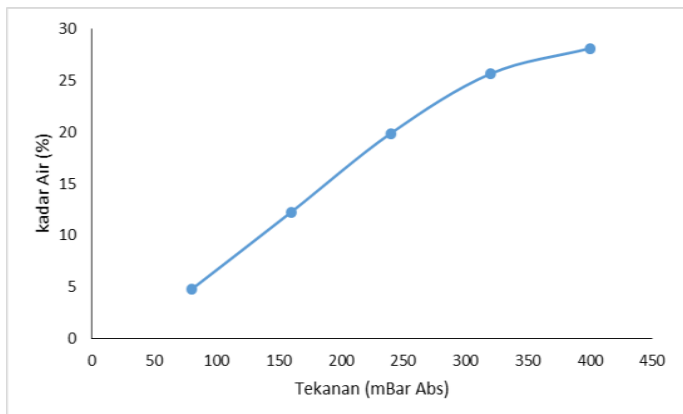

Gambar 3. Grafik pengurangan massa vs tekanan

Dari variasi nilai tekanan tersebut, tekanan 80 mbar menghasilkan telur yang kering dan pengurangan massa air terbesar yaitu sebesar 33,76 gram dan 
kadar air sebesar 4,76\%, sehingga tekanan operasi yang dipilih adalah 80 mbar. Menurut Astuti, 2008 kondisi operasi yang dipilih dapat memberikan pengaruh nyata terhadap kadar air produk, yang dibuktikan pada penelitiannya dalam pengeringan bawang merah dengan tekanan 200 mbar, didapatkan penurunan kadar air yang cukup besar yaitu mencapai 56,99\% dari kadar air dalam bawang merah sebesar $65 \%$ sedangkan menurut Bell dan Weaver, 2002 telur memiliki kandungan air sebesar 75,5\%, sehingga penentuan tekanan 80 mbar Absolut dapat diterima, karena kadar air bawang merah dan telur hampir sama.

\section{Penentuan Waktu Maksimum dalam Pengeringan dengan Oven Vakum \\ Waktu pengeringan maksimal} ditentukan berdasarkan percobaan pendahuluan (tray dryer) yang dilakukan, yaitu pada saat menghasilkan berat konstan dari telur yang dikeringkan. Suhu yang digunakan dalam penelitian menggunakan oven vakum $44^{\circ} \mathrm{C}$. Suhu ini digunakan berdasarkan sifat telur yang bisa mengalami kerusakan kandungan (denaturasi) protein pada suhu diatas $60^{\circ} \mathrm{C}$ (Baldwin, dkk, 2010), juga menurut Ndife, dkk, 2010 penggunaan suhu tersebut tidak mempengaruhi sifat fisik, fungsional dan gizi. Perbedaan produk yang dihasilkan ini dapat dilihat pada gambar berikut :

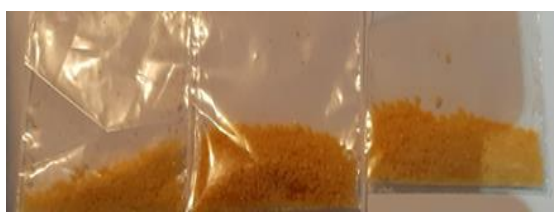

Gambar 4. Perbandingan produk serbuk telur

Pengurangan massa air pada telur terhadap waktu pengeringan sebagai berikut:

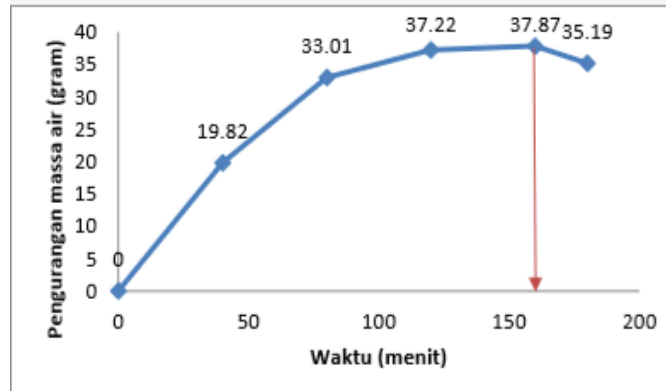

Gambar 5. Grafik pengurangan massa vs waktu pengeringan

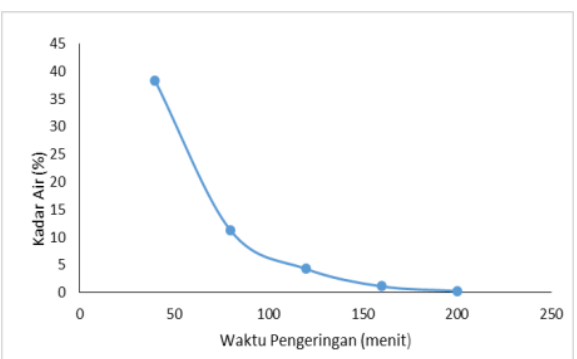

Gambar 6. Grafik kadar air vs waktu pengeringan

Dari grafik kadar air vs waktu pengeringan dapat dilihat bahwa produk yang dihasilkan dengan waktu pengeringan selama 120, 160 dan 200 menit memberikan nilai kadar air sebesar $4,76 \%$, kurang dari nilai pada tray dryer (kadar air kesetimbangan) sebesar 4,84\%) disebabkan alat pengering vakum yang digunakan memberikan kondisi hampir kedap udara sehingga menyebabkan tekanan parsial udara jauh lebih kecil dibandingkan tekanan uap air pada telur. Menurut Sokhansanj, 1995, kandungan air kesetimbangan merupakan kandungan air pada tekanan parsial udara sama dengan tekanan uap air pada bahan.

Dari percobaan tersebut didapatkan waktu pengeringan optimum pada oven vakum sebesar 160 menit dan memberikan pengurangan massa air yang paling besar yaitu 37,87 gram dan kadar air akhir sebesar $1,12 \%$.

Berdasarkan hasil yang didapat, kondisi yang digunakan untuk pembuatan serbuk telur ini adalah suhu $44^{\circ} \mathrm{C}$, tekanan 80 mbar dan waktu 160 menit. 


\section{Analisis kadar protein dan lemak pada serbuk telur}

Kadar protein dalam serbuk telur perlu dipertahankan agar nilai gizi dari telur tetap tinggi setelah dilakukan pengeringan dalam oven vakum. Pengujian protein menggunakan metode Spektrofotometri Biuret dan pengujian lemak menggunakan Ekstraksi Soxhlet. Hasil yang didapatkan dari analisis protein dan lemak diperlihatkan pada gambar 7.

Kandungan protein pada telur tinggi, yaitu sebesar $12,8-13,4 \%$ / berat telur, dengan pengeringan diharapkan tidak turun.

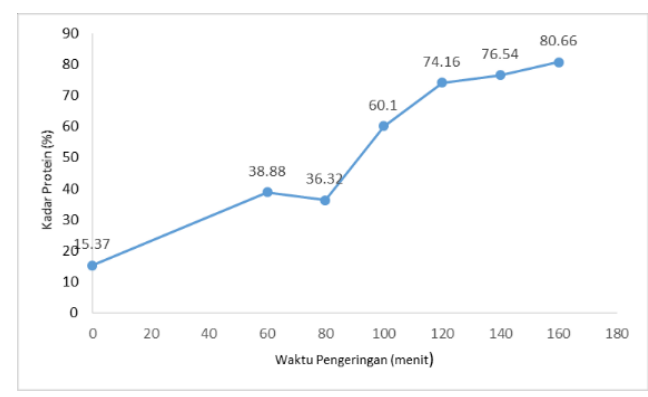

Gambar 7. Kurva Kadar Protein vs Waktu Pengeringan

Dari grafik terlihat dari menit ke 60 sampai 160 menit terjadi perubahan sebesar 15,37-80,66\%. Peningkatan terjadi karena kadar air sudah tidak ada sehingga memudahkan dalam penyerapan warna saat reduksi menggunakan $\mathrm{Cu}$. Penentuan protein dengan spektrofotometri metode pereduksi biuret, dengan melihat kadar protein standar terhadap absorbansi.

Kadar lemak diharapkan tidak mengalami penurunan dalam pengeringan, penentuan kadar lemak kurang memberikan hasil yang akurat, karena dalam penelitian ini penentuan kadar lemak dilakukan dengan penimbangan padatan secara gravimetri. Kondisi ini berpengaruh karena kadar abu, kandungan protein yang terlarut dalam pelarut dan kotoran berupa endapan ikut terukur, sehingga menaikkan hasil yang didapat. Sesuai penelitian Yuniarti, dkk 2013, penurunan kadar air berbanding lurus dengan kadar lemak, sehingga semakin kering kadar lemak semakin turun. Pengamatan dalam penelitian ini tidak terjadi, tetapi terlihat bahwa kadar lemak dari menit ke 80 sampai 160 terjadi penurunan 43,53 $37,47 \%$.

\section{Analisis Produk Serbuk Telur Setelah Penyimpanan}

Pengamatan produk serbuk telur yang dihasilkan setelah 25 hari dalam penyimpanan plastik tertutup dan kering. tidak mengalami perubahan, meliputi penampilan, warna dan bau. Dari kondisi ini dapat disimpulkan bahwa kandungan air yang rendah 4, 76\% menyebabkan mikroba tidak tumbuh, sehingga kualitas dari serbuk telur tidak rusak. Disamping itu dari produk telur setelah penghilangan lemak didapatkan serbuk yang berwarna putih, menunjukkan bahwa kandungan yang ada pada serbuk telur hanya protein, bau yang ditimbulkan juga anyir.

\section{SIMPULAN}

Dari penelitian yang dilakukan didapatkan kesimpulan sebagai berikut:

Kondisi proses pengeringan menggunakan oven vakum dilakukan pada suhu $44^{\circ} \mathrm{C}$, tekanan 80 mbar Absolut dan waktu 160 menit, yang didapatkan dengan menentukan waktu pengeringan sampai air dalam telur berada dalam kesetimbangan dengan udara. Kandungan nilai gizi serbuk telur tidak mengalami kerusakan, hal ini diperlihatkan pada hasi pengujian, kadar protein dalam telur setelah mengalami pengeringan tidak terdegradasi, diperlihatkan dari hasil pengamatan dari menit ke 60 - 160 sebesar 15,37-80,66\%. Sedangkan kandungan lemak dari menit ke 80 - 160 mengalami penurunan dari 43,53-37,47\%. Penyimpanan telur setelah 25 hari tidak mengalami kerusakan secara fisik dan bau. 


\section{DAFTAR RUJUKAN}

Astuti. 2018. Pengaruh Suhu dan Lama Pemanasan dengan Menggunakan Ekstraktor Vakum terhadap Crude Albumin Ikan Gabus (Ophiocephalus striatus). Jurnal Protein, Vol 15, No.2.

Bell D. \& Weaver, G. 2002. Commercial Chicken Meat and Egg, Kluwer Academic Publishers, United States of America.

Baldwin, dkk. 2010. Protein, Structure, Function, Wiley Online Library.

Cotterill, OJ \& Geiger GS. 1977. Egg Product Yield trends from Shell Eggs. Poultry Science 56: 1027 1031 .

Henderson, S. M., \& Perry. R. L. 1976. Agricultural Process Engineering 3rd ed. The AVI Publ. Co., Inc, Westport, Connecticut, USA.

Kumaravel. 2012. Effect of Oven drying on the nutritional properties of whole egg and its components. International Jurnal of Food and Nutrition Science

Ndife, Joel. 2010. Effect of Oven Drying on The Functional and Nutritional Properties of Whole egg and Its Component. International Jurnal of Food and Nutrition Science, Vol 4(5): 254-257.
Robert, J. R. 2004. Factor affecting eggs internal quality and eggshell quality in laying hens. Journal Poultry Science, Vol 41: 161-177.

Stadelman, W. J. \& O. J. Cotteril. 1995. Egg Science and Technology. 4th Ed. Food Products Press. An Imprint of the Haworth Press, Inc. New York

Sokhansanj. 1995. Moisture sorption and volumetric changes of canola during hydrothermal processing. Journal of Food Process Engineering, Vol 18 No.3

Winarno. 1993. Pangan, Gizi, Teknologi dan Konsumen. PT Gramedia Pustaka Utama, Jakarta.

Winarno, 1994, Sterilisasi Komersial Produk-produk Pangan. Gramedia Jakarta.

Yuniarti, 2013. Pengaruh Suhu Pengeringan Vakum Terhadap Kualitas Serbuk Albumin Ikan Gabus (Ophiocephalus striatus). Universitas Brawijaya, Malang. 